\title{
QUANTITATIVE REAL-TIME PCR (Q-PCR) FOR SPUTUM SMEAR DIAGNOSIS OF PULMONARY TUBERCULOSIS AMONG PEOPLE WITH HIVIAIDS
}

\author{
Yvana Maria Maia de ALBUQUERQUE(1,3), Ana Luiza Magalhães de Andrade LIMA(5), Ana Kelly LINS(2), Marcelo MAGALHÃES(2) \& Vera MAGALHÃES(1,2,4)
}

\begin{abstract}
SUMMARY
Objective: To assess quantitative real-time polymerase chain reaction (q-PCR) for the sputum smear diagnosis of pulmonary tuberculosis (PTB) in patients living with HIV/AIDS with a clinical suspicion of PTB. Method: This is a prospective study to assess the accuracy of a diagnostic test, conducted on 140 sputum specimens from 140 patients living with HIV/AIDS with a clinical suspicion of PTB, attended at two referral hospitals for people living with HIV/AIDS in the city of Recife, Pernambuco, Brazil. A Löwenstein-Jensen medium culture and 7H9 broth were used as gold standard. Results: Of the 140 sputum samples, 47 (33.6\%) were positive with the gold standard. q-PCR was positive in $42(30 \%)$ of the 140 patients. Only one $(0.71 \%)$ did not correspond to the culture. The sensitivity, specificity and accuracy of the q-PCR were $87.2 \%, 98.9 \%$ and $95 \%$ respectively. In 39 (93\%) of the 42 q-PCR positive cases, the CT (threshold cycle) was equal to or less than 37. Conclusion: q-PCR performed on sputum smears from patients living with HIV/AIDS demonstrated satisfactory sensitivity, specificity and accuracy, and may therefore be recommended as a method for diagnosing PTB.
\end{abstract}

KEYWORDS: HIV/AIDS/tuberculosis co-infection; Diagnosis; Real time PCR.

\section{INTRODUCTION}

Infection by the human immunodeficiency virus (HIV) is an important risk factor in the development of tuberculosis (TB). HIV increases not only the risk of reactivating latent Mycobacterium tuberculosis (MTB) but also the re-infection of the disease ${ }^{7}$. The annual risk of progressing to TB amongst coinfected patients varies between five and 15\%, depending on the degree of immunosuppression, against $0.5 \%$ and $1 \%$ in noncoinfected patients ${ }^{12}$.

In most cases, pulmonary tuberculosis (PTB) in those living with HIV/AIDS presents itself in an atypical clinical form, and from a clinical or radiological viewpoint is very often indistinguishable from other opportunistic infections ${ }^{7}$.

Conventional laboratory techniques used for diagnosing PTB, such as the sputum smear test by Ziehl-Neelsen staining, which despite being inexpensive, presents low sensitivity since most coinfected patients have paucibacillary diseases ${ }^{9,16,17}$. Although the culture has a greater sensitivity of between 19 and $96 \%$, and a specificity of $100 \%$, and is the gold standard, it takes between four and eight weeks to obtain results ${ }^{13,15,16}$.

In daily practice, it is common to prescribe anti-TB drugs for patients living with HIV/AIDS, without any confirmation of TB-disease, due to diagnostic difficulties and severity of symptoms. This conduct frequently leads to complications, not only due to the toxicity of anti-TB drugs, but also because of the interaction between these drugs and antiretroviral therapy (ART).

Studies have suggested that the inclusion of quantitative real-time polymerase chain reaction (q-PCR) is a method that may assist in diagnosing a variety of infections, including that caused by MTB $^{5,6,8,10}$. q-PCR eliminates the gel electrophoresis steps in order to assess the results. Thus, it is a quicker, more sensitive technique, which also presents a lower risk of causing environmental contamination ${ }^{6,8}$.

The aim of the present study is to assess q-PCR's effectiveness in confirming a diagnosis of PTB in sputum from patients living with HIV/ AIDS and with a clinical suspicion of PTB.

\section{METHODOLOGY}

This was a prospective study to assess the accuracy of a diagnostic test, conducted between August 2009 and January 2012. A total of 140 patients were included in the study who were aged 18 and over, HIV-infected and with a clinical suspicion of PTB, and who were attending two referral hospitals for HIV/AIDS in the city of Recife, Pernambuco, Brazil. Patients were excluded from the study if they were 


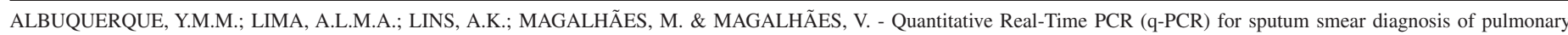
tuberculosis among people with HIV/AIDS. Rev. Inst. Med. Trop. Sao Paulo, 56(2): 139-42, 2014.

taking anti-TB drugs or were unable to provide sputum samples for the study.

All patients tested HIV-positive, which was conducted by enzyme immunoassay (ELISA, Abbott Laboratories) and confirmed by immunofluorescence or Western blot, as required by the Ministry of Health (Ordinance No. 59).

A sputum sample was collected from each patient. With patients who were unable to produce sputum spontaneously, sputum induction was performed with nebulized $3 \%$ hypertonic saline, for 20 minutes, with the aim of obtaining suitable material for the tests ${ }^{2,14}$. Collected data was stored in the study's database.

Sputum decontamination was undertaken with the $\mathrm{NaOH}-\mathrm{N}$-acetyl cysteine method. With the obtained sediment, slides were prepared for direct testing, performed with the Ziehl-Neelsen staining technique, and seeded in Löwenstein-Jensen solid medium (LJ (Difco-USA)) and 7H9 broth (Becton-Dickinson Co. MD-USA). The remaining sediment was maintained at $-80^{\circ} \mathrm{C}$ until the q-PCR was conducted to identify the DNA of the MTB complex.

The cultivated material was examined twice per week during the first two weeks and once per week over the course of eight weeks. The culture, gold standard, was considered positive when at least one of the media presented mycobacterial growth. Furthermore, to confirm the identity of the species $M$. tuberculosis within the MTB complex, a commercial niacin accumulation test was performed (Becton, Dickinson).

The q-PCR methodology used was previously published by LEMAITRE et al. ${ }^{10}$ and involved:

Step 1: Extraction of DNA from sputum: Tissue Protocol using the QIAamp DNA mini kit, following manufacturer's recommendations, manufactured by Qiagen, Hilden, Germany.

Step 2: DNA Amplification: In summary: Primers and probes were used for IS6110 (Gene Bank No. X52471), designed from Primer Express Software, 2.0 (BIOSYTEMS), obtained from Applied Biosystems, Warrington, UK. The nucleotide sequences of the primers were: 5'- CCGAGGCAGGCATCCA-3' (position 1062 to 1077) and 5'-GATCGTCTCGGCTAGTGCATT-3' (position 1112 to 1132). The sequence of the probe was 5'-FAM-TCGGAAGCTCCTATGAC-MGB-3' (position 1095 to 1111).

PCR amplification was performed in triplicate with a total volume of $25 \mu \mathrm{L}$ containing the TaqMan Universal PCR master mix 2X (Applied Biosytems), with $300 \mathrm{nM}$ of each primer, $200 \mathrm{nM}$ probe and $5 \mu \mathrm{L}$ of extracted DNA. A BioRad iCycler IQ 5 Thermal Cycler was used, with the following conditions: two minutes at $50^{\circ} \mathrm{C}, 10$ minutes at $95^{\circ} \mathrm{C}$ and 50 cycles at $95^{\circ} \mathrm{C}$ for 15 seconds and $60^{\circ} \mathrm{C}$ for one minute. The q-PCR was analyzed with Bio-Rad iQ5 1.0 software. For each reaction, positive and negative controls were used.

All positive culture tests for mycobacteria and q-PCR negative tests for MTB were submitted to the q-PCR test to identify MTB complexes, M.avium-intracellulare, M.chelonaelabscessus and M.kansasi, using primers and probes designed by LEUNG et al. ${ }^{11}$
Patients were assessed at the moment of collecting the material, reassessed after the culture results, observing the response to anti-TB treatment.

In order to undertake data analysis, rates were obtained for sensitivity, specificity, positive predictive values, negative predictive values and accuracy. The Kappa index was used to compare the LJ and 7H9 media. The Pearson's chi-squared test was used to assess the association between categorical variables; a 5\% margin of error. The program used for typing in all data and for obtaining the calculations was SPSS 17.

The present study was approved by the Ethics Committee at the Centro de Ciências da Saúde at Universidade Federal de Pernambuco (UFPE), Protocol No. 01.470.172.000-09

\section{RESULTS}

A total of 140 sputum specimens from 140 patients living with HIV/AIDS with a clinical suspicion of PTB were analyzed. Of these, $47(33.6 \%)$ were confirmed by culture, and $78(55.7 \%)$ were male. Ages ranged from 19 to 64 years, a mean age of 37.13 years, a median of 36 years and a standard deviation of 9.86 years.

In 37 (26.4\%) of the 140 patients, the direct sputum test with ZiehlNeelsen staining was positive. Sensitivity, specificity, positive predictive value (PPV), negative predictive value (NPV) and accuracy of the direct test was $78.7 \%, 100 \%, 100 \%, 90.3 \%$ and $92.8 \%$, respectively (Table 1).

q-PCR was positive in $42(30 \%)$ of the 140 patients. Sensitivity, specificity, PPV, NPV and accuracy of the q-PCR were respectively: $87.2 \%, 98.9 \%, 97.6 \%, 93.9 \%$ and $95 \%$ (Table 1 ).

Of the 42 patients with positive q-PCR results, 39 (93\%) presented a threshold cycle $(\mathrm{Ct})$ equal to or less than 37 . The sensitivity of the q-PCR, considering this $\mathrm{Ct}$ value as indicative of positivity, was $92.3 \%$, the PPV was $97.5 \%$ and the accuracy was $92.9 \%$. It was not possible to determine the specificity and NPV due to the low frequency (one case) of negative results, when compared to the culture, the gold standard method.

The CD4 T-cell count varied between two and 1301 cells $/ \mathrm{mm}^{3}$ presenting a median value of 148.50 . No statistically significant difference was observed between the q-PCR results and the value of the CD4 cells, $p=0.952$ (Pearson chi-squared test).

\section{DISCUSSION}

Of the 140 patients studied with a clinical suspicion of PTB, only 47 (33.6\%) confirmed PTB with culture, the gold standard method. However, anti-TB treatment was initiated in $75(53.6 \%)$ patients, $28(20 \%)$ of whom initiated treatment without diagnostic confirmation. According to the reviewed medical records a therapeutic response to anti-TB treatment was observed in just eight $(5.7 \%)$ of these patients and they were considered PTB cases with a negative culture. Due to the high frequency and severity of this coinfection, as well as the difficulty of arriving at a diagnosis with culture empirical treatment for TB is not uncommon in patients living with HIV/AIDS and respiratory symptoms. However, this conduct does not always prove beneficial, since coinfected patients present more adverse reactions to anti-TB drugs ${ }^{3}$. Moreover, there may be an interaction 


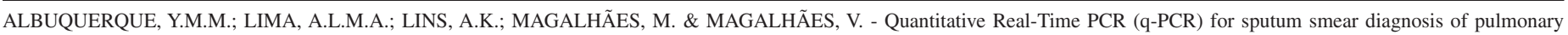
tuberculosis among people with HIV/AIDS. Rev. Inst. Med. Trop. Sao Paulo, 56(2): 139-42, 2014.

Table 1

Comparison between qPCR and the direct test with the results of the culture (gold standard): sensitivity (S), specificity (Sp), positive predictive value (PPV), negative predictive value (NPV) and accuracy (A)

\begin{tabular}{|c|c|c|c|c|c|c|c|c|}
\hline \multirow{2}{*}{ Test } & \multicolumn{2}{|c|}{ Gold standard } & \multirow{2}{*}{ Total } & \multicolumn{5}{|c|}{ Percentage measurements } \\
\hline & Positive & Negative & & $\mathrm{S}$ & $\mathrm{Sp}$ & PPV & NPV & A \\
\hline \multicolumn{9}{|l|}{ - PCR-1 } \\
\hline Positive & 41 & 1 & 42 & 87.2 & 98.9 & 97.6 & 93.9 & 95.0 \\
\hline Negative & 6 & 92 & 98 & & & & & \\
\hline Total & 47 & 93 & 140 & & & & & \\
\hline \multicolumn{9}{|l|}{ - BAAR } \\
\hline Positive & 37 & - & 37 & 78.7 & 100.0 & 100.0 & 90.3 & 92.8 \\
\hline Negative & 10 & 93 & 103 & & & & & \\
\hline Total & 47 & 93 & 140 & & & & & \\
\hline
\end{tabular}

(1): PCR was only positive in 42 patients.

between the anti-TB drugs and antiretroviral therapy, which may impose limitations on the therapeutic response of these patients. These facts reinforce the importance of a rapid, safe diagnostic test, so as to reduce the number of these unnecessary treatments.

The sensitivity and specificity of the direct test were $78.7 \%$ and $100 \%$ respectively, where sensitivity was higher and specificity similar to other studies. In the direct test, KIBIKI et al. 2007 encountered a sensitivity of $66 \%$, while REWATA et al. 2009, encountered $66.7 \%$ and SCHERER et al. 2011, 60\%. The PPV and NPV of the direct test were $100 \%$ and $90.3 \%$ respectively. The PPV was similar and the NPV was higher to that encountered by REWATA et al. 2009, who obtained a NPV of $83.3 \%$. The high sensitivity of the direct test in the present study is probably related to the method of obtaining the sputum samples. The sputum induction technique was used for $26(18.6 \%)$ patients who were complaining of a dry cough. Induced sputum samples are of good quality, similar to those obtained with bronchoalveolar lavage (BAL) obtained by bronchoscopy ${ }^{2,14}$. Furthermore, the direct test was conducted after sputum decontamination and subsequent centrifugation, which may have contributed to the test's greater sensitivity.

The q-PCR demonstrated a sensitivity and specificity of $87.2 \%$ and $98.9 \%$, respectively. These findings were similar to those of KIBIKI et al. 2007, who performed q-PCR with the BAL of patients living with HIV/AIDS. In KIBIKI's study, the results for sensitivity were $85.7 \%$ and $96.4 \%$ and for specificity were $52.3 \%$ and $90.9 \%$ with $\mathrm{Ct}$ values of 32 and 40. It is important to emphasize that the present study used sputum in the q-PCR assessment, while KIBIKI et al. 2007, used BAL. Since similar results were obtained, this would suggest that sputum induction using a nebulizer is equivalent to BAL, demonstrating how this procedure could be useful in regions where it is difficult to perform a bronchoscopy.

Of the 42 positive q-PCRs, only one was not confirmed by culture, this patient supplied a relatively substantial amount of $M$. tuberculosis DNA $(\mathrm{Ct}=35)$ and a satisfactory response to anti-TB treatment, suggesting a failure of the culture. In fact, the sensitivity of the culture, despite being gold standard, may not be so high in paucibacillary patients. The sensitivity of the culture in coinfected patients varies between 19 and $96 \%{ }^{15}$.
The population levels of CD4 T-cells cannot be related to the results of the q-PCR. This demonstrates the usefulness of this test for diagnosing PTB at all stages of HIV infection. In patients with advanced AIDS, with low CD4 counts, PTB appears in an atypical form, and may be confused with several other infections ${ }^{12}$. The early, effective diagnosis of PTB is essential in order to ensure proper patient care, as well as reducing the transmission of $\mathrm{MTB}^{1}$.

It may be concluded that q-PCR, performed on sputum samples obtained either spontaneously or after induction, yields satisfactory levels of sensitivity, specificity and accuracy. Thus, given that q-PCR is a quick technique, it is recommended for routine use in the management of patients living with HIV/AIDS.

\section{RESÚMEN}

\section{Reacción en cadena de polimerasa en tiempo real cuantitativa (qPCR) para el diagnóstico de tuberculosis pulmonar en esputo de pacientes con VIH/sida}

Objetivo: Evaluar la Reacción en Cadena de Polimerasa en tiempo real cuantitativa (qPCR) para el diagnóstico de tuberculosis pulmonar (TBP) en esputo de pacientes con sida y sospecha clínica de TBP. Método: Se trata de un estudio prospectivo para evaluación de precisión de prueba diagnóstica, realizado en 140 muestras de esputo provenientes de 140 pacientes con sida y sospecha clínica de TBP atendidos en dos hospitales de referencia para atención VIH/sida en Recife-PE, Brasil. Se utilizó el cultivo en medios Löwenstein-Jensen y 7H9 como estándar de oro. Resultados: De las 140 muestras de esputo, 47 (33,6\%) fueron positivas por el estándar de oro. La qPCR fue positiva en 42 (30\%) de los pacientes. En apenas un $(0.71 \%)$ caso no correspondió con el cultivo. La sensibilidad, especificidad y precisión de la qPCR fueron $87,2 \%, 98,9 \%$ y $95 \%$ respectivamente. De las 42 qPCR positivas en 39 (93\%) el CT (threshold cycle) fue igual o inferior a 37. Conclusión: La qPCR realizada en muestra de esputo de pacientes con sida demostró sensibilidad, especificidad y precisión satisfactoria, pudiendo ser recomendada como método de diagnóstico de TBP. 
ALBUQUERQUE, Y.M.M.; LIMA, A.L.M.A.; LINS, A.K.; MAGALHÃES, M. \& MAGALHÃES, V. - Quantitative Real-Time PCR (q-PCR) for sputum smear diagnosis of pulmonary tuberculosis among people with HIV/AIDS. Rev. Inst. Med. Trop. Sao Paulo, 56(2): 139-42, 2014.

\section{ACKNOWLEDGEMENTS}

The authors would like to express their gratitude to Laboratório Marcelo Magalhães for their support in performing the sputum smear tests.

The authors declare that they have no conflicts of interest.

\section{REFERENCES}

1. Boehme CC, Nabeta P, Hillemann D, Nicol MP, Shenai S, Krapp F, et al. Rapid molecular detection of tuberculosis and rifampin resistance. N Engl J Med. 2010;363:1010-5.

2. Conde MB, Soares SLM, Mello FCQ, Resende VM, Almeida LL, Reingold AL, et al. Comparison of sputum induction with fiberoptic bronchoscopy in the diagnosis of tuberculosis: experience at an acquired imumune deficiency syndrome reference center in Rio de Janeiro, Brazil. Am J Respir Crit Care Med. 2000;162:2238-40.

3. De Lima MFS, Melo HRL. Hepatotoxicity induced by antituberculosis drugs among patients coinfect with HIV and tuberculosis. Cad Saude Publica. 2012;28:698-708.

4. El-Sadr WM, Tsiouris SJ. HIV-associated tuberculosis: diagnostic and treatment challenges. Semin Respir Crit Care Med. 2008;29:525-31.

5. Espy MJ, Uhl JR, Sloan LM, Buckwalter SP, Jones MF, Vetter EA, et al. Real-time PCR in clinical microbiology: applications for routine. Clin Microbiology Rev. 2006;19:165256.

6. Giulietti A, Overbergh L, Valckx D, Decallonne B, Bouillon R, Mathieu C. An overview of real-time quantitative PCR: applications to quantify cytokine gene expression. Methods. 2001;25:386-401.

7. Kibiki GS, Mulder B, Ven AJAM, Sam N, Boeree MJ, Zanden A, et al. Laboratory diagnosis of pulmonary tuberculosis in TB and HIV endemic settings and the contribution of real time PCR for M. tuberculosis in bronchoalveolar lavage fluid. Trop Med Int Health. 2007;12:1210-7.

8. Kim K, Lee H, Lee M, Lee S, Shim T, Lim SY, et al. Development and application of multiprobe real-time PCR method targeting the $h s p 65$ gene for differentiation of Mycobacterium species from isolates and sputum specimens. J Clin Microbiol. 2010;48:3073-80
9. Kivihya-Ndugga L, van Cleeff M, Juma E, Kimwomi J, Githui W, Oskam L, et al. Comparison of PCR with the routine procedure for diagnosis of tuberculosis in population with high prevalences of tuberculosis and human immunodeficiency virus. J Clin Microbiol. 2004;42:1012-5.

10. Lemaitre N, Armand S, Vachée A, Capilliez O, Dumoulin C, Courcol RJ. Comparison of the real time PCR method and the Gen-Probe amplified Mycobacterium tuberculosis direct test for detection of Mycobacterium tuberculosis in pulmonary and nonpulmonary specimens. J Clin Microbiol. 2004;42:4307-9.

11. Leung KI, Yip CW, Cheung WF, Lo ACT, Ko WM, Kam KM. Development of a simple and a low-cost real-time PCR method for the identification of commonly encountered mycobacteria in a high throughput laboratory. J Appl Microbiol. 2009;107:1364-77.

12. Melo FAF, Afiune JB, Hijja MA, Gomes M, Rodrigues DSS, Klautau GB, et al. Coinfect tuberculosis and HIVAIDS. In: Veronesi R, Focaccia R, editors Treaty of infectology. $4^{\text {th }}$ ed. São Paulo: Atheneu; 2009. p. 1313-21.

13. Padmapriyadarsini C, Narendran G, Swaminathan S. Diagnosis and treatment of tuberculosis in HIV co-infected patients. Indian J Med Res. 2011;134:850-65.

14. Parry CM, Kamoto O, Harries AD, Wirima JJ, Nyirenda CM, Nyangulu DS, et al. The use of sputum induction for establishing a diagnosis in patients with suspected pulmonary tuberculosis in Malawi. Tuber Lung Dis.1995;76:72-6.

15. Rewata L, Rutherford M, Apriani L, Janssen W, Rahmadi A, Parwati I, et al. Improving diagnosis of pulmonary tuberculosis among HIV/AIDS patients: literature review and experience in teaching hospital in Indonesia. Acta Med Indones. 2009;41(Suppl 1):57-64.

16. Scherer LC, Sperhacke RD, Jaraziwski C, Cafrune PI, Michelon CT, Ruperthal R, et al Comparison of two laboratory-developed PCR methods for the diagnosis of pulmonary tuberculosis in Brazilian patients with and without HIV infection. BMC Pulm Med. 2011;11:15. http//www.biomedcentral.com/1471-2466/11/15

17. van Cleeff M, Kivihya-Ndugga L, Githnui W, Ng'ang'a L, Kibuga D, Odhiambo J, et al. Cost-effectiveness of polymerase chain reaction versus Ziehl-Neelsen smear microscopy for diagnosis of tuberculosis in Kenya. Int J Tuberc Lung Dis. 2005;9:87783.

Received: 16 November 2012

Accepted: 1 August 2013 